\title{
Hubungan antara Usia Ibu dan Paritas dengan Kejadian Hyperemesis Gravidarum
}

Juliana Widyastuti Wahyuningsih

Akademi Kebidanan Budi Mulia Palembang

\section{Informasi Artikel :}

Diterima : 02 April 2020

Direvisi : 10 April 2020

Disetujui : 03 Mei 2020

*Korespondensi Penulis : yuliana_widyastuti@ymail.com

\section{A B S T R A K}

Hiperemesis gravidarum adalah kondisi mual dan muntah yang berat selama kehamilan, yang terjadi pada $1-2 \%$ dari semua kehamilan atau 1-20 pasien per 1000 kehamilan. Hyperemesis gravidarum tidak hanya mengancam kehidupan perempuan, namun dapat menyebabkan efek samping pada janin seperti abortus, berat badan lahir rendah, kelahiran prematur dan malformasi pada bayi baru lahir. Kasus kematian pada hyperemesis gravidarum terjadi sebesar 159 kematian per 1000 kelahiran di Inggris. Selain dampak fisiologis pada kehidupan klien dan janinnya, hyperemesis juga memberikan dampak secara psikologis, sosial, spiritual, dan pekerjaan. Tujuan penelitian ini adalah untuk mengetahui hubungan antara umur dan gravida dengan kejadian hyperemesis gravidarum pada ibu hamil di Rumah Sakit Umum Daerah Banyuasin Tahun 2019. Penelitian ini menggunakan metode survey analitik dengan pendekatan Cross Sectional. Sampel dalam penelitian ini adalah seluruh ibu hamil trimester 1 dan trimester II yang pernah dirawat di Rumah Sakit Umum Daerah Banyuasin Tahun 2019 berjumlah 198 responden. Penelitian ini dilakukan pada bulan Februari 2020. Sampel penelitian diambil secara random sampling dengan teknik Simple random sampling. Analisa data menggunakan uji statistik Chi-Square dengan $\alpha(0,05)$. Hasil penelitian ini menunjukkan bahwa tidak ada hubungan yang bermakna antara usia ibu dengan kejadian hyperemesis gravidarum dengan $P$ value $(0,604)$ dan tidak ada hubungan yang bermakna antara paritas dengan kejadian hyperemesis gravidarum dengan $P$ value $(0,972)$. Saran bagi rumah sakit dapat dijadikan masukan dalam mengupayakan pengembangan tatalaksana asuhan kebidanan dalam meningkatkan mutu pelayanan kesehatan terutama pada kasus-kasus yang berhubungan dengan kejadian hyperemesis gravidarum.

\section{Kata Kunci : emesis, nausea, hyperemesis gravidarum}

\section{ABSTRACT}

Hyperemesis gravidarum is a condition of severe nausea and vomiting during pregnancy, which occurs in 1-2\% of all pregnancies or 1-20 patients per 1000 pregnancies. Hyperemesis gravidarum not only threatens the lives of Women, but can cause side effects on the fetus such as abortion, low birth weight, premature birth and malformations in newborns. Cases of death in hyperemesis gravidarum occur at 159 deaths per 1000 births in the UK. In addition to physiological effects on the lives of clients and their fetuses, hyperemesis also has psychological, social, spiritual, and work impacts. The purpose of this study is to determine the relationship between age and gravida with the incidence of hyperemesis gravidarum in pregnant women at the Banyuasin Regional General Hospital in 2019. This study used an analytical survey method with a cross sectional approach. The samples in this study were all trimester 1 and second trimester pregnant women who had been treated at the Banyuasin Regional General Hospital 
in 2019 totaling 198 respondents. This research was conducted in February 2020. The research sample was taken by random sampling with Simple random sampling technique. Data analysis used Chi-Square statistical test with a (0.05). The results of this study indicate that there is no significant relationship between maternal age with the incidence of hyperemesis gravidarum with $P$ value (0.604) and there is no significant relationship between parity with the incidence of hyperemesis gravidarum with $P$ value (0.972). Suggestions for hospitals can be used as input in seeking the development of midwifery care management in improving the quality of health services, especially in cases related to the occurrence of hyperemesis gravidarum.

Keywords: emesis, nausea, hyperemesis gravidarum

\section{PENDAHULUAN}

Hiperemesis gravidarum adalah kondisi mual dan muntah yang berat selama kehamilan, yang terjadi pada $1-2 \%$ dari semua kehamilan atau 1-20 pasien per 1000 kehamilan. Mual dan muntah merupakan gangguan yang paling sering kita jumpai pada kehamilan muda dan dikemukakan oleh 50\% dari wanita yang hamil, terutama dikemukakan pada primigravida, kehamilan ganda dan mola hydatidosa. Tetapi kalau seorang ibu memuntahkan segala apa yang dimakan dan diminum hingga berat badan sangat turun, turgor kulit kurang, diurese kurang dan timbul aseton dalam air kencing, maka keadaan ini disebut Hyperemesis gravidarum dan memerlukan perawatan di rumah sakit. ${ }^{1}$

Menurut Organisasi Kesehatan Dunia atau World Health Organization (WHO), kematian ibu didefinisikan sebagai kematian yang terjadi saat masa kehamilan atau dalam kurun waktu 42 hari setelah persalinan. Di Indonesia, Angka Kematian Ibu (AKI) masih tergolong tinggi. Berdasarkan data tahun 2012, angka kematian ibu cukup tinggi, yaitu sekitar 359 per 100.000 per kelahiran. Rasio kematian ibu di sembilan negara maju dan 51 negara persemakmuran. Terlebih lagi, rendahnya penurunan angka kematian ibu global tersebut merupakan cerminan belum adanya penurunan angka kematian ibu secara bermakna di negaranegara yang angka kematian ibunya rendah. Artinya, Negara-negara dengan angka kematian ibu tinggi belum menunjukkan kemajuan berarti dalam 15 tahun terakhir ini. ${ }^{2}$

Hyperemesis gravidarum tidak hanya mengancam kehidupan klien, namun dapat menyebabkan efek samping pada janin seperti abortus, berat badan lahir rendah, kelahiran prematur dan malformasi pada bayi baru lahir. Kasus kematian pada hyperemesis gravidarum terjadi sebesar 159 kematian per 1000 kelahiran di Inggris. Selain dampak fisiologis pada kehidupan klien dan janinnya, hyperemesis juga memberikan dampak secara psikologis, sosial, spiritual, dan pekerjaan. ${ }^{3}$

Menurut Departemen Kesehatan RI tahun 2008 jika dibandingkan Angka kematian ibu di Singapura adalah 6 per 100.000 kelahiran hidup, Angka kematian ibu di Malaysia mencapai 160 per 100.000 kelahiran hidup. Bahkan Angka kematian ibu di Vietnam sama seperti Negara Malaysia, sudah mencapai 160 per 100.000 kelahiran hidup, Filipina 112 per 100.000 kelahiran hidup, Brunei Darussalam 33 per 100.000 per kelahiran hidup, sedangkan di Indonesia 228 per 100.000 kelahiran hidup. Menurut departemen kesehatan pada tahun 2010, penyebab langsung kematian maternal di Indonesia terkait kehamilan dan persalinan terutama yaitu perdarahan $28 \%$. Sebab lain, yaitu eklampsi $24 \%$, infeksi $11 \%$, partus lama $5 \%$, dan abortus $5 \%{ }^{4}$

Jumlah kematian ibu di provinsi Sumatera Selatan tahun 2014 sebanyak 155 orang, naik menjadi 164 orang kematian pada tahun 2015, turun menjadi 142 orang pada tahun 2016 dan turun lagi menjadi 107 orang tahun 2017 dan naik menjadi 119 orang pada tahun $2018 .^{6}$

Berdasarkan hasil penelitian di Provinsi Sumatera Selatan tahun 2009 menjelaskan bahwa lebih dari $80 \%$ perempuan hamil mengalami rasa mual dan muntah sedangkan untuk perempuan hamil yang mengalami kondisi Hyperemesis gravidarum sekitar 5 dari 1.000 perempuan hamil. Hal ini bisa menyebabkan perempuan menghindari makanan tertentu dan biasanya membawa resiko bagi-nya dan janin .

Jumlah Kematian Maternal tahun 2018 tertinggi terjadi di kabupaten Banyuasin sebanyak 15 orang, kabupaten Musi Banyuasin sebanyak 13 orang dan kabupaten Musi Rawas sebanyak 12 orang, Sedangkan jumlah kematian ibu maternal terendah terjadi di kota Prabumulih 
sebanyak 1 orang, kota Pagar Alam sebanyak 2 orang, kabupaten Empat Lawang sebanyak $3 .^{8}$

Berdasarkan data dari Medical Record RSUD Banyuasin, angka kejadian ibu yang mengalami Hyperemesis gravidarum pada tahun 2013 ada 62 orang dari 393 Ibu hamil. Berdasarkan latar belakang diatas, peneliti tertarik untuk melakukan penelitian kesehatan yang berjudul "Hubungan antara Umur dan Gravida dengan Kejadian Hyperemesis Gravidarum pada Ibu Hamil di RSUD Banyuasin Tahun 2019.

\section{METODE PENELITIAN}

Jenis penelitian ini menggunakan metode survey analitik dengan pendekatan "Cross Sectional" yaitu suatu penelitian yang semua variabelnya, baik variabel independen maupun variabel dependen diobservasi atau dikumpulkan sekaligus dalam waktu yang bersamaan. ${ }^{9}$ Adapun variabel yang akan diteliti yaitu variabel independen (umur dan gravida), serta variabel dependen (kejadian hyperemesis gravidarum).

Populasi dalam penelitian ini adalah seluruh ibu hamil yang pernah dirawat di RSUD Banyuasin tahun 2019 sebanyak 393 responden.

Pengambilan sampel ini dilakukan dengan metode random sampling dengan teknik Acak Sederhana (Simple Random Sampling) yaitu setiap anggota atau unit dari populasi mempunyai kesempatan yang sama untuk diseleksi sebagai sampel penelitian. 9

Analisa univariat digunakan untuk melihat distribusi frekuensi dari masing-masing variabel, baik variabel dependen maupun variabel independen. ${ }^{9}$ Dalam penelitian ini variabel dependen adalah kejadian hyperemesis gravidarum, sedangkan variabel independen adalah umur dan gravida.

Analisa bivariat digunakan untuk melihat hubungan antara variabel dependen (kejadian hyperemesis gravidarum) maupun variabel independen (umur dan gravida). Untuk menguji tingkat kemaknaan dilakukan uji statistic $C h i$ Square $(x 2)$ dengan batas kemaknaan $(\alpha)=0,05$, confidence interval $(C I)=95 \%$ yang menggunakan sistem komputerisasi. Keputusan dari pengujian Chi-Square yaitu jika nilai $p$ value $\leq \alpha$ : Ho ditolak dan Ha diterima yang berarti ada hubungan yang bermakna antara umur dan gravida dengan kejadian hyperemesis gravidarum dan bila $p$ Value $>\alpha$ : Ha ditolak dan Ho diterima yang berarti tidak ada hubungan bermakna antara umur dan gravida dengan kejadian hyperemesis gravidarum.
HASIL PENELITIAN

1. Analisa Univariat

a. Umur

Tabel 1 Distribusi Frekuensi Responden Berdasarkan Umur Ibu Hamil di Rumah Sakit Umum Daerah Banyuasin

\begin{tabular}{cccc}
\hline No & Umur & F & Persentase \\
\hline 1. & Resiko Tinggi & 51 & 25,8 \\
2. & Resiko Rendah & 147 & 74,2 \\
\hline & Jumlah & $\mathbf{1 9 8}$ & $\mathbf{1 0 0 , 0}$ \\
\hline
\end{tabular}

Berdasarkan tabel 1 dapat diketahui bahwa dari 198 responden, yang termasuk umur resiko tinggi sebanyak 51 responden $(25,8 \%)$ dan yang termasuk umur resiko rendah sebanyak 147 responden $(74,2 \%)$.

\section{b. Gravida}
Tabel 2 Distribusi Frekuensi Responden Berdasarkan Gravida Ibu Hamil di Rumah Sakit Umum Daerah Banyuasin

\begin{tabular}{clcc}
\hline No & Gravida & F & Persentase \\
\hline 1. & Primigravida & 62 & 31,3 \\
2. & Multigravida & 136 & 68,7 \\
\hline & Jumlah & $\mathbf{1 9 8}$ & $\mathbf{1 0 0 , 0}$ \\
\hline
\end{tabular}

Berdasarkan tabel 2 dapat diketahui bahwa dari 198 responden, yang termasuk primigravida sebanyak 62 responden $(31,3 \%)$ dan yang termasuk multigravida sebanyak 136 responden $(68,7 \%)$.

\section{c. Kejadian Hyperemesis Gravidarum}

Tabel 3 Distribusi Frekuensi Responden Berdasarkan Kejadian Hyperemesis Gravidarum di Rumah Sakit Umum Daerah Banyuasin

\begin{tabular}{cccc}
\hline No & $\begin{array}{c}\text { Kejadian } \\
\text { Hyperemesis } \\
\text { Gravidarum }\end{array}$ & F & Persentase \\
\hline 1. & Ya & 46 & 23,2 \\
2. & Tidak & 152 & 76,8 \\
\hline & Jumlah & $\mathbf{1 9 8}$ & $\mathbf{1 0 0 , 0}$ \\
\hline
\end{tabular}

Berdasarkan tabel 3 dapat diketahui bahwa dari 198 responden, yang mengalami hyperemesis gravidarum sebanyak 46 responden $(23,2 \%)$ dan yang tidak mengalami hyperemesis gravidarum sebanyak 152 responden $(76,8 \%)$. 
2. Analisis Bivariat
a.Hubungan Umur Ibu Hamil dengan Kejadian Hyperemesis Gravidarum

Tabel 4 Distribusi Hubungan Umur Ibu Hamil dengan Kejadian Hyperemesis Gravidarum di Rumah Sakit Umum Daerah Banyuasin

\begin{tabular}{|c|c|c|c|c|c|c|c|c|}
\hline \multirow{3}{*}{$\begin{array}{c}\mathbf{N} \\
\mathbf{0}\end{array}$} & \multirow{3}{*}{ Umur } & \multicolumn{4}{|c|}{ Kejadian HEG } & \multirow{2}{*}{\multicolumn{2}{|c|}{ Jumlah }} & \multirow{3}{*}{$\begin{array}{c}P \\
\text { value }\end{array}$} \\
\hline & & \multicolumn{2}{|c|}{ Ya } & \multicolumn{2}{|c|}{ Tidak } & & & \\
\hline & & n & $\%$ & $\mathbf{n}$ & $\%$ & $\mathbf{N}$ & $\%$ & \\
\hline 1. & $\begin{array}{l}\text { Resiko } \\
\text { Tinggi }\end{array}$ & 10 & 19,6 & 41 & 80,4 & 51 & 100 & \\
\hline 2. & $\begin{array}{l}\text { Resiko } \\
\text { Rendah }\end{array}$ & 36 & 24,5 & 111 & 75,5 & 147 & 100 & 0,604 \\
\hline \multicolumn{2}{|c|}{ Jumlah } & 46 & & 152 & & 198 & & \\
\hline
\end{tabular}

Berdasarkan Tabel 4 dari 51 responden yang termasuk umur resiko tinggi yang mengalami kejadian hyperemesis gravidarum sebanyak 10 responden $(19,6 \%)$, sedangkan dari 147 responden yang termasuk umur resiko rendah yang mengalami kejadian hyperemesis gravidarum sebanyak 36 responden (24,5\%).

Dapat disimpulkan bahwa responden yang termasuk umur resiko tinggi yang mengalami kejadian hyperemesis gravidarum lebih sedikit dibandingkan dengan responden yang termasuk umur resiko rendah yang mengalami kejadian hyperemesis gravidarum.

Berdasarkan hasil uji statistik dengan menggunakan Chi-square menunjukkan tidak ada hubungan yang bermakna antara umur ibu hamil dengan kejadian hyperemesis gravidarum, dimana $p$ value $=0,604$ lebih besar dari $\alpha=0,05$ sehingga Ha ditolak dan Ho diterima yang berarti tidak ada hubungan yang bermakna antara umur ibu hamil dengan kejadian hyperemesis gravidarum.

\section{b. Hubungan Gravida Ibu Hamil dengan Kejadian Hyperemesis Gravidarum}

Tabel 5 Distribusi Hubungan Gravida Ibu Hamil dengan Kejadian Hyperemesis Gravidarum di Rumah Sakit Umum Daerah Banyuasin

\begin{tabular}{|c|c|c|c|c|c|c|c|c|}
\hline \multirow{3}{*}{$\begin{array}{l}\mathbf{N} \\
\mathbf{0}\end{array}$} & \multirow{3}{*}{ Gravida } & \multicolumn{4}{|c|}{ Kejadian HEG } & \multirow{2}{*}{\multicolumn{2}{|c|}{ Jumlah }} & \multirow{3}{*}{$\begin{array}{c}P \\
\text { value }\end{array}$} \\
\hline & & \multicolumn{2}{|c|}{ Ya } & \multicolumn{2}{|c|}{ Tidak } & & & \\
\hline & & $\mathbf{n}$ & $\%$ & $\mathbf{n}$ & $\%$ & $\mathbf{N}$ & $\%$ & \\
\hline 1 & Primigravida & 15 & 24,2 & 47 & 75,8 & 62 & 100 & \multirow{3}{*}{0,972} \\
\hline 2 & Multigravida & 31 & 22,8 & 105 & 77,2 & 136 & 100 & \\
\hline \multicolumn{2}{|c|}{ Jumlah } & 46 & & 152 & & 198 & & \\
\hline
\end{tabular}

Berdasarkan Tabel 5 dari 62 responden yang termasuk primigravida yang mengalami kejadian hyperemesis gravidarum sebanyak 15 orang (24,2\%), sedangkan dari 136 responden yang termasuk multigravida yang mengalami kejadian hyperemesis gravidarum sebanyak 31 orang $(22,8 \%)$.

Dapat disimpulkan bahwa responden yang termasuk primigravida yang mengalami kejadian hyperemesis gravidarum lebih sedikit dibandingkan dengan responden yang termasuk multigravida yang mengalami kejadian hyperemesis gravidarum.

Berdasarkan hasil uji statistik dengan menggunakan Chi-square menunjukkan tidak ada hubungan yang bermakna antara gravida ibu hamil dengan kejadian hyperemesis gravidarum, dimana $p$ value $=0,972$ lebih besar dari $\alpha=0,05$ sehingga Ha ditolak dan Ho diterima yang berarti tidak ada hubungan yang bermakna antara gravida ibu hamil dengan kejadian hyperemesis gravidarum.

\section{PEMBAHASAN}

\section{Kejadian Hyperemesis Gravidarum}

Penelitian kejadian hyperemesis gravidarum pada ibu hamil dibagi menjadi dua kategori yaitu ya (bila diagnosa dokter terkena HEG) dan tidak (bila diagnosa dokter selain HEG). Data dikumpulkan dengan cara mencatat langsung dari rekam medik pada seluruh ibu hamil TM I yang pernah dirawat di Rumah Sakit Umum Daerah Banyuasin dengan menggunakan check list.

Dari penelitian ini jumlah responden yang mengalami hyperemesis gravidarum sebanyak 46 responden $(23,2 \%)$ lebih sedikit dibandingkan dengan jumlah responden yang tidak mengalami hyperemesis gravidarum sebanyak 152 responden $(76,8 \%)$.

Teori menyatakan hyperemesis gravidarum yaitu mual dan muntah berlebihan pada ibu hamil, sampai mengganggu aktivitas sehari-hari karena keadaan umumnya menjadi buruk, yang dirawat inap di rumah sakit. ${ }^{1}$

Pada penelitian ini responden yang mengalami hyperemesis gravidarum lebih sedikit dibandingkan dengan responden yang tidak mengalami hyperemesis gravidarum, dimungkinkan karena terdapatnya faktor lain seperti molahidatidosa, abortus, dan gemeli, tetapi peneliti tidak melakukan penelitian terhadap kemungkinan tersebut. 


\section{Umur}

Pada penelitian ini umur ibu hamil dibagi menjadi dua kategori, yaitu resiko tinggi (jika umur ibu $<20$ tahun dan $>35$ tahun) dan resiko rendah (jika umur ibu 20-35 tahun). Data dikumpulkan dengan cara mencatat langsung dari rekam medik pada seluruh ibu hamil TM I yang pernah dirawat di Rumah Sakit Umum Daerah Banyuasin dengan menggunakan check list.

Berdasarkan hasil analisa univariat didapatkan jumlah responden yang termasuk umur resiko tinggi sebanyak 51 responden $(25,8 \%)$ lebih sedikit dibandingkan dengan jumlah responden yang termasuk umur resiko rendah sebanyak 147 responden $(74,2 \%)$.

Berdasarkan hasil analisa bivariat dari 51 responden yang termasuk umur resiko tinggi sebanyak 10 responden $(19,6 \%)$ yang mengalami kejadian hyperemesis gravidarum, sedangkan dari 147 responden yang termasuk umur resiko rendah sebanyak 36 responden $(24,5 \%)$ yang mengalami kejadian hyperemesis gravidarum. Hasil uji statistik Chi-square dimana $p$ value $(0,604)$ lebih besar dari $\alpha=(0,05)$ yang berarti tidak ada hubungan yang bermakna antara umur ibu hamil dengan kejadian hyperemesis gravidarum di Rumah Sakit Umum Daerah Banyuasin

Teori menyatakan bahwa ibu hamil lebih beresiko menderita hyperemesis gravidarum pada umur $<20$ dan $>35$ tahun. Pada ibu yang terlalu muda atau berumur $<20$ tahun, masih terlalu muda secara fisiologis dan fungsional rahim seorang ibu belum sepenuhnya berfungsi secara optimal dan secara psikologis belum siap untuk hamil dan menjadi orang tua, sehingga terjadi konflik mental yang membuat ibu tidak memperhatikan asupan nutrisinya yang menyebabkan terjadinya iritasi lambung sehingga menimbulkan reaksi pada impuls motorik untuk memberi rangsangan pada pusat muntah. Sedangkan untuk ibu yang umurnya semakin tua atau >35 tahun mengakibatkan terjadinya penurunan fungsi termasuk organ reproduksi dan secara psikologis ibu merasa tidak sanggup lagi untuk hamil yang dapat memacu stres dan merangsang hipotalamus serta merangsang pusat muntah di otak. ${ }^{9}$

Hasil penelitian ini tidak sejalan dengan hasil penelitian yang dilakukan oleh Ismail tahun 2011 di Puskesmas Mattirobulu, Kecamatan Mattirobulu, Kabupaten Pinrang, ditemukan bahwa dari 50 responden didapatkan 16 orang (32\%) mempunyai umur berisiko tinggi, terdapat 9 orang (18\%) mengalami hyperemesis gravidarum dan 7 orang (14\%) tidak mengalami hyperemesis gravidarum. Sedangkan dari 34 orang (68\%) mempunyai umur berisiko rendah, terdapat 7 orang (14\%) mengalami hyperemesis gravidarum dan 27 orang (54\%) yang tidak mengalami hyperemesis gravidarum. Hasil uji statistic Chi Square Test, diperoleh nilai $p$ value $=0,012$. Dengan demikian dapat dibuktikan secara statistic adanya hubungan umur dengan kejadian hyperemesis gravidarum pada ibu hamil. $^{10}$

Hasil penelitian ini tidak sejalan dengan hasil penelitian yang dilakukan oleh Razak (2010) di Rumah Sakit Angkatan Laut Jala Ammari Tahun 2009 dari 38 responden didapatkan penyebab Hyperemesis Gravidarum pada ibu hamil berdasarkan umur ibu dengan resiko tinggi (umur $<20$ tahun dan $>35$ tahun) jumlahnya $73,68 \%$ lebih besar dibandingkan dengan resiko rendah (umur 20 tahun sampai 35 tahun) yaitu sebanyak 26,32 \%. Jadi Ho ditolak dan Ha diterima berarti ada hubungan antara umur ibu hamil dengan kejadian hyperemesis gravidarum. ${ }^{11}$

Hasil penelitian ini sejalan dengan hasil penelitian yang dilakukan oleh Nurul Ardianti tahun 2012 di Rumah Sakit Umum Bhakti Yhuda Depok ditemukan bahwa dari 76 responden didapatkan ibu yang mengalami hyperemesis gravidarum tingkat I (ringan) berumur $<20$ dan $>35$ tahun adalah sebanyak 21 orang $(27,6 \%)$ dan yang berumur 20 -35 tahun adalah sebanyak 29 orang $(38,2 \%)$. Dan diketahui pula bahwa ibu yang mengalami hyperemesis gravidarum tingkat II (sedang) berumur $<20$ dan $>35$ tahun adalah sebanyak 7 orang $(9,2 \%)$ dan yang berumur 20 35 tahun adalah sebanyak 19 orang $(25,0 \%)$. Dengan P-Value sebesar 0,297 dan nilai tersebut lebih besar dari 0,05 , sehingga dapat disimpulkan bahwa pada penelitian ini tidak terdapat hubungan antara umur ibu dengan tingkatan hyperemesis gravidarum. ${ }^{12}$

Pada penelitian ini tidak ditemukan adanya hubungan yang bermakna antara umur ibu hamil dengan kejadian hyperemesis gravidarum, dimungkinkan karena terdapatnya faktor lain yang dapat mempengaruhi umur resiko tinggi, seperti keinginan kuat memiliki seorang buah hati, dukungan suami dan orang-orang terdekat serta faktor lain yang dapat mempengaruhi faktor psikologis dari seorang ibu sehingga dapat mengatasi masalah-masalah yang dapat memacu timbulnya stres yang dapat merangsang pusat muntah di otak, tetapi peneliti tidak melakukan penelitian terhadap kemungkinan tersebut. 
Berdasarkan hasil uji statistik dengan menggunakan Chi-square menunjukkan $p$ value $=0,604$ lebih besar dari $\alpha=0,05$ sehingga $\mathrm{Ha}$ ditolak dan Ho diterima yang berarti tidak ada hubungan yang bermakna antara umur ibu hamil dengan kejadian hyperemesis gravidarum.

\section{Gravida}

Pada penelitian ini gravida ibu hamil dibagi menjadi dua kategori, yaitu primigravida (jika ibu hamil pertama kali) dan multigravida (jika ibu hamil lebih dari satu kali). Data dikumpulkan dengan cara mencatat langsung dari rekam medik pada seluruh ibu hamil TM I yang pernah dirawat di Rumah Sakit Umum Daerah Banyuasin dengan menggunakan check list.

Berdasarkan hasil analisa univariat didapatkan jumlah responden yang termasuk primigravida sebanyak 62 responden $(31,3 \%)$ lebih sedikit dibandingkan dengan jumlah responden yang termasuk multigravida sebanyak 136 responden $(68,7 \%)$.

Berdasarkan hasil analisa bivariat dari 62 responden yang termasuk primigravida sebanyak 15 orang $(24,2 \%)$ yang mengalami kejadian hyperemesis gravidarum, sedangkan dari 136 responden yang termasuk multigravida sebanyak 31 orang $(22,8 \%)$ yang mengalami kejadian hyperemesis gravidarum. Hasil uji statistik Chisquare dimana $p$ value $(0,972)$ lebih besar dari $\alpha$ $=(0,05)$ yang berarti tidak ada hubungan yang bermakna antara gravida ibu hamil dengan kejadian hyperemesis gravidarum di Rumah Sakit Umum Daerah Banyuasin

Teori menyatakan Primigravida dan gravida $\geq 4$ lebih berisiko mengalami komplikasi persalinan daripada gravida 2-4 (Lubis, 2013). Hyperemesis gravidarum lebih banyak terjadi pada kehamilan primigravida dari pada multigravida. $^{7}$

Hasil penelitian ini tidak sejalan dengan hasil penelitian yang di lakukan oleh Husnaini tahun 2011 di Puskesmas Mangkurawang, Kecamatan Tenggarong, Kabupaten Kutaikartanegara, didapatkan 22 responden primigravida hampir semua mengalami hyperemesis gravidarum yaitu 21 responden $(52 \%)$ dan 1 responden tidak mengalami hyperemesis gravidarum. Sedangkan untuk 18 responden multigravida atau grandemultigravida sebagian kecil mengalami hyperemesis gravidarum yaitu 2 responden (3\%) dan sebagian besar tidak mengalami hyperemesis gravidarum yaitu 16 responden (40\%). Dari hasil uji statistik menggunakan uji chi kuadrat dengan taraf signifikan $\alpha=0,05$ dengan $\mathrm{dk}=1$ didapatkan bahwa $x^{2}$ hitung $>x^{2}$ tabel yaitu 28,82 > 3,841 jadi Ho ditolak dan Ha diterima. Hal ini berarti ada hubungan antara status gravida dengan kejadian hyperemesis gravidarum pada ibu hamil.

Hasil penelitian ini tidak sejalan dengan hasil penelitian yang dilakukan oleh Henny (2011) di RB Ibunda Kecamatan Karangrejo dengan jumlah sampel 40 responden menghasilkan uji statistik menggunakan uji chi kuadrat dengan taraf signifikan $\alpha=0,05$ dengan $\mathrm{dk}=1$ didapatkan bahwa $\mathrm{x}^{2}$ hitung $>\mathrm{x}^{2}$ tabel yaitu 28,82 > 3,841 jadi Ho ditolak dan Ha diterima. Hal ini berarti ada hubungan antara status gravida dengan kejadian hyperemesis gravidarum pada ibu hamil trimester I.

Hasil penelitian ini sejalan dengan hasil penelitian yang dilakukan oleh Nurul Ardianti tahun 2012 di Rumah Sakit Umum Bhakti Yhuda Depok ditemukan bahwa dari 76 responden didapatkan ibu yang mengalami hyperemesis gravidarum tingkat I (ringan) golongan primigravida adalah sebanyak 22 orang $(28,9 \%)$ dan golongan multigravida adalah sebanyak 28 orang $(36,8 \%)$. Dan diketahui pula bahwa ibu yang mengalami hyperemesis gravidarum tingkat II (sedang) golongan primigravida adalah sebanyak 13 orang $(17,1 \%)$ dan golongan multigravida adalah sebanyak 13 orang $(17,1 \%)$. Dengan P-Value sebesar 0,798 dan nilai tersebut lebih besar dari 0,05 , sehingga dapat disimpulkan bahwa pada penelitian ini tidak terdapat hubungan antara gravida dengan tingkatan hyperemesis gravidarum. ${ }^{12}$

Pada penelitian ini tidak ditemukan adanya hubungan yang bermakna antara gravida ibu hamil dengan kejadian hyperemesis gravidarum, dimungkinkan karena terdapatnya faktor-faktor yang dapat mempengaruhi wanita hamil seperti faktor intern dari dalam pribadi ibu yang dipengaruhi oleh faktor pekerjaan, pendidikan, keadaan ekonomi dan latar belakang budaya yang bisa mempengaruhi faktor stres atau psikologis ibu yang bisa merangsang pusat muntah di otak, tetapi peneliti tidak melakukan penelitian terhadap kemungkinan tersebut.

Berdasarkan hasil uji statistik dengan menggunakan Chi-square menunjukkan $p$ value $=0,972$ lebih besar dari $\alpha=0,05$ sehingga $\mathrm{Ha}$ ditolak dan Ho diterima yang berarti tidak ada hubungan yang bermakna antara gravida ibu hamil dengan kejadian hyperemesis gravidarum. 


\section{KESIMPULAN DAN SARAN}

Berdasarkan hasil penelitian yang telah dilakukan di Rumah Sakit Umum Daerah Banyuasin mengenai hubungan antara umur dan gravida dengan kejadian hyperemesis gravidarum pada ibu hamil dengan sampel 198, maka dapat disimpulkan bahwa tidak ada hubungan yang bermakna antara umur ibu hamil dengan kejadian hyperemesis gravidarum di Rumah Sakit Umum Daerah Banyuasin $p$ value $=0,604>0,05$. Tidak ada hubungan yang bermakna antara gravida ibu hamil dengan kejadian hyperemesis di Rumah Sakit Umum Daerah Banyuasin Tahun $2013 p$ value $=0,972>0,05$.

\section{A. Saran}

1. Bagi Pihak Rumah Sakit

Sebagai bahan informasi dan masukan dalam menetapkan kebijakan kualitas dan mutu pelayanan bagi masyarakat terutama bagi ibu-ibu hamil yang mengalami Hyperemesis Gravidarum. Selain itu diharapkan petugas kesehatan mampu memberikan penyuluhan pencegahan guna menurunkan angka kejadian Hyperemesis gravidarum.

2. Bagi Institusi Pendidikan

Hasil penelitian ini dapat dijadikan sebagai dokumentasi agar dapat digunakan untuk bahan perbandingan dalam melaksanakan penelitian. Selain itu juga dapat dijadikan sebagai bahan referensi di perpustakaan, memberikan informasi dan pengetahuan dalam proses belajar mengajar bagi dosen dan mahasiswa Akademi Kebidanan Budi Mulia Palembang khususnya mengenai masalah Hyperemesis gravidarum.

3. Bagi Peneliti yang akan datang

Hasil penelitian ini dapat digunakan sebagai bahan referensi untuk melakukan penelitian serta sumber penelitian yang akan datang agar penelitian berikutnya bisa dilakukan dengan variabel-variabel yang berbeda dengan metode yang berbeda dan sampel yang lebih banyak.

\section{DAFTAR PUSTAKA}

1. Pudiastuti Ratna Dewi. 2012. Asuhan Kebidanan Pada Hamil Normal dan Patologi. Yogyakarta: Nuha Medika.

\section{BKKBN.2008. World Health Organization.} $2008 . \quad$ Kematian

(http://www.bkkbn.go.id).
3. Hidayati, Ratna. 2009. Asuhan Keperawatan pada Kehamilan Fisiologis dan Patologis. Jakarta: Salemba Medika.

4. Departemen kesehatan Sumsel. 2017. Profil Kesehatan Sumatera Selatan. Palembang.

5. Departemen kesehatan RI. 2018. Profil Kesehatan Indonesia 2007. Jakarta

6. Departemen kesehatan Pemerintah Provinsi Sumatera Selatan.2019.Rencana Kinerja Tahunan Dekonsentralisasi Dinas Kesehatan Tahun 2019.2 https://erenggar.kemkes.go.id/file2018/eperformance/2-110009-2tahunan-847.pdf

7. Fauziyah, Yulia. 2012. Obstetri Patologi. Yogyakarta: Nuha Medika.

8. Manuaba, Ida Ayu Chandranita, dkk. 2010. Ilmu Kebidanan, Penyakit Kandungan, dan $K B$. Jakarta: EGC.

9. Notoatmodjo, Soekidjo. 2010. Metodologi Penelitian Kesehatan. Jakarta : Rineka Cipta.

10.Florensa. 2013. Hubungan Antara Umur dan Gravida Dengan Kejadian Hiperemesis Gravidarum di Rumah Sakit Muhammadiyah Palembang Tahun 2012.

11.Razak.2010. Faktor-faktor yang Berhubungan Dengan Kejadian Hyperemesis Gravidarum Pada Ibu Hamil di di Rumah Sakit Angkatan Laut Jala Ammari Tahun 2009.

12.Nurul Ardianti.2012. Hubungan Antara Usia Ibu dan Status Gravida Dengan Kejadian Hiperemesis Gravidarum di Rumah Sakit Umum Bhakti Yhuda Depok. 
